\title{
Genotoxicity Revaluation of Three Commercial Nitroheterocyclic Drugs: Nifurtimox, Benznidazole, and Metronidazole
}

\author{
Annamaria Buschini,, ${ }^{1}$ Lisa Ferrarini, ${ }^{1}$ Susanna Franzoni, ${ }^{1}$ Serena Galati, ${ }^{1}$ \\ Mirca Lazzaretti, ${ }^{1}$ Francesca Mussi, ${ }^{1}$ Cristina Northfleet de Albuquerque, ${ }^{2}$ \\ Tânia Maria Araújo Domingues Zucchi, ${ }^{3}$ and Paola Poli ${ }^{1}$
${ }^{1}$ Dipartimento di Genetica, Biologia dei Microrganismi, Antropologia, Evoluzione, Università di Parma, Parco Area delle Scienze, 11/a, 43100 Parma, Italy
${ }^{2}$ Departamento de Tecnologia Bioquímico Farmacêutica, Faculdade de Ciências Farmacêuticas, USP, Avenida Prof. Lineu Prestes, 580, Cidade Universitária, 05508-900 São Paulo, Brazil
${ }^{3}$ Departamento de Parasitologia, Instituto de Ciências Biomédicas, USP, Avenida Prof. Lineu Prestes, 1374, Cidade Universitária, \\ 05508-900 São Paulo, Brazil
}

Correspondence should be addressed to Paola Poli, paola.poli@unipr.it

Received 24 April 2009; Revised 9 July 2009; Accepted 3 August 2009

Recommended by José F. Silveira

Nitroheterocyclic compounds are widely used as therapeutic agents against a variety of protozoan and bacterial infections. However, the literature on these compounds, suspected of being carcinogens, is widely controversial. In this study, cytotoxic and genotoxic potential of three drugs, Nifurtimox (NFX), Benznidazole (BNZ), and Metronidazole (MTZ) was re-evaluated by different assays. Only NFX reduces survival rate in actively proliferating cells. The compounds are more active for base-pair substitution than frameshift induction in Salmonella; NFX and BNZ are more mutagenic than MTZ; they are widely dependent from nitroreduction whereas microsomal fraction S9 weakly affects the mutagenic potential. Comet assay detects BNZ- and NFXinduced DNA damage at doses in the range of therapeutically treated patient plasma concentration; BNZ seems to mainly act through ROS generation whereas a dose-dependent mechanism of DNA damaging is suggested for NFX. The lack of effects on mammalian cells for MTZ is confirmed also in MN assay whereas MN induction is observed for NFX and BNZ. The effects of MTZ, that shows comparatively low reduction potential, seem to be strictly dependent on anaerobic/hypoxic conditions. Both NFX and BNZ may not only lead to cellular damage of the infective agent but also interact with the DNA of mammalian cells.

Copyright (C) 2009 Annamaria Buschini et al. This is an open access article distributed under the Creative Commons Attribution License, which permits unrestricted use, distribution, and reproduction in any medium, provided the original work is properly cited.

\section{Introduction}

The introduction of nitro-substituted heterocyclic drugs, such as nitroimidazoles and nitrofurans, heralded a new era. 5-Nitrofurans and 2- and 5-nitroimidazoles are the classes of nitroheterocyclic drugs most used in the treatment of infections caused by anaerobic bacteria and a range of pathogenic protozoan parasites [1-4].

Nitrofuran derivatives do not interact with DNA per se, but they require metabolic conversion for exerting their action $[5,6]$. These compounds are metabolically activated to the corresponding hydroxylamines through the reduction of their functional nitro group [7].

Nifurtimox (NFX, N-(3-methyl-1,1-dioxo-1,4-thiazinan-4-yl)-1-(5-nitro-2-furyl) methane-mine, CAS number
23256-30-6) is a 5-nitrofuran for the treatment of Chagas' disease (American trypanosomiasis), which affects more than 10 million people in Central and South America. Controversial results are reported for NFX in the treatment in the second stage of African sleeping sickness [8-10]. One possible mechanism of action of NFX as trypanocidal involves the ability of this agent to form a nitro-anion radical metabolite, which reacts with the nucleic acids of the parasite, causing a significant breakage in the DNA [4], and the other involves the production of superoxide anions and hence hydrogen peroxide $[4,11]$. The drug exhibits particularly serious toxic side effects on patients $[12,13]$ generally attributed to NFX nitroreductive biotransformation to a nitroanion radical, redox cycling, generation of reactive oxygen species or lipid peroxidation 
$[14,15]$, production of peroxinitrite radicals [16], and other nitrite-forming processes [17]. Induction of mutants by NFX [18-24], but not by its in vivo metabolites [25], was found in bacterial systems. It exhibited genotoxic effects on Drosophila melanogaster [26], and it caused chromosomal aberrations (CA), micronucleus (MN) and sister-chromatid exchange (SCE) formation [27-29]. NFX was found to increase cancer incidence $[30,31]$ but did not exhibit initiating carcinogenic activities [32].

Nitroimidazol derivatives are reported to exert their therapeutic effect through nitrogroup reduction $[2,3]$. Antibacterial and antiprotozoal activity appears to result from the formation of short-lived protonated one-electron nitro radical anions and other compounds, including nitroso and hydroxylamine derivatives [3] following reduction of the nitrogroup by nitroreductases present in the bacterial or protozoal cell. This intermediate species interacts with DNA, causing strand breaks with helix destabilization, this preventing DNA synthesis and, thereby, causing cell death in both bacteria and protozoal parasites [33, 34].

The 2-nitroimidazol benznidazole (BNZ, N-benzyl-2(2-nitroimidazol-1-yl)acetamide, CAS number 22994-85-0) is the only etiological treatment commercially available for Chagas disease in many countries from Latin America. This drug appears to inhibit protein and ribonucleic acid (RNA) synthesis in the parasite. As NFX, BNZ induces serious toxic side effects [12]. Several free radical species similar to those produced by NFX were thought to be involved $[4,14]$. It is mutagenic for Salmonella typhimurium [19, 20, 22, 33-36] as well as the urine and blood of treated animals [25]. Its clastogenic ability is controversial since both positive [27, 28, 3743 ] and negative [44] findings are reported. Carcinogenicity bioassays reported cancer induction [30,31].

The 2-nitroimidazol metronidazole (MTZ, 2-(2-methyl5-nitro-1H-imidazol-1-yl)ethanol, CAS number 443-48-1) possesses direct trichomonacidal and amebacidal activity and shows clinical activity against most obligate anaerobes $[1,45]$. The drug is active when reduced under strongly reducing conditions [46] through electron donation from ferredoxin or flavodoxin, oxidoreductase [47], and possibly forming an hydroxylamine [48]. Presumably, free radicals are formed which, in turn, react with cellular components resulting in death of the microorganism as also supported by some findings on the protective role of antioxidants against MTZ [49]. However, scavenging activities of MTZ on free oxygen radicals were reported [50-52]. It has been also suggested that the reactive species are intermediates in the reductive metabolism of MTZ, which leads to the formation of acetamide [53]. Mutagenic activity, induced by the drug [22] as well as by the urine of therapeutically treated patients $[54,55]$, was found in bacterial systems. In mammalian cells, some studies [33, 34, 56-65] indicate that MTZ causes a loss of DNA helix content, strand breakage, unscheduled DNA synthesis, and SCEs, whereas others [66-72] do not confirm its genotoxicity. In some in vivo studies, MTZ was found genotoxic $[73,74]$. In many others [68, 71, 75-79] these effects were not registered. Some data [80] cannot be clearly interpreted. Some positive effects $[57,66]$ have been discussed [81] as to be the result of an infection of the cells with mycoplasms. According to the International Agency for Research on Cancer [82], the evidence is sufficient to consider MTZ as an animal carcinogen [83-87] but insufficiently for humans [88].

For chemotherapy of Chagas' disease, NFX and BNZ display most efficacy against the extracellular forms of $T$. cruzi during the acute phase of the infection, whereas both drugs are considered to be, at best, only partially beneficial against the intracellular form that causes chronic disease [8994]. Furthermore, the severe side effects of both drugs limit their use [12, 13, 92-94]. MTZ is currently the drug of choice for treating invasive amoebiasis, but it may not be sufficient to eliminate parasite cysts in the intestine. Moreover, some unpleasant adverse effects associated with metronidazole in some patients, and the possibility of parasite resistance to metronidazole has to be considered [95]. Treatment of patients with Clostridium difficile infection with MTZ generally reduces morbidity and mortality, although the number of patients that do not respond is increasing [9698]. There are insufficient data to recommend the use of metronidazole in persistent diarrhoea of unknown cause or nonspecific cause [99]. Furthermore, these compounds were suspected of being mutagens and carcinogens $[3,4,7,15,27-$ $29,31,33,34,94,100]$.

The literature on these widely used drugs is controversial. To come to a more clear statement with respect to the mode of action we re-evaluated their genotoxic and cytotoxic potential with different in vitro test, that is, Salmonella reverse mutation assay [101], comet assay [102], micronucleus assay $[103,104]$, and short- and long-term cytotoxicity assays.

\section{Materials and Methods}

2.1. Chemicals. Reagents for electrophoresis, normal melting point and low melting point agarose, dimethyl sulfoxide (DMSO), ethidium bromide (EtBr), 5-carboxyfluorescein diacetate (FDA), Hoechst 33342 (HO), ethyl methane sulfonate (EMS), hycantone (HYC), 2-aminofluorene (2$\mathrm{AF}$ ), cell culture medium, buffers, and general laboratory chemicals were from Sigma (Sigma-Aldrich Company Ltd., Milan, Italy). Lyophilized postmitochondrial supernatant rat liver fraction S9 was from MOLTOX INC. (Boone, NC, USA); Bleomycin from Rhône-Poulenc Rorer (Collegeville, PE, USA); Furylfuramide (2-(2-furyl)-3-(5-nitro2-furyl)acrylamide) from Wako Pure Chemical Industries (Osaka, Japan). Nifurtimox (Bayer 2502, Lampit) was from Bayer. Benznidazole (Rochagan) was from Roche Brasil (Rio de Janeiro, Brazil). Metronidazole was from Fluka SigmaAldrich (Buchs, Swiss) and Bieffe Medital SPA (Grosotto, SO, Italy).

2.2. Salmonella/Microsome Test. The bacteria reverse mutation assay [101] on different his-Salmonella typhimurium strains was used to evaluate the mutagenic properties of the compounds. TA100 strain is predominantly sensitive to base pair substitution mutagens whereas TA98 is sensitive to frameshift mutagens. The strains are deficient in excision repair (uvrB mutation) and contain the plasmid pKM101, 
which activates an error prone DNA repair system, making them more responsive to a variety of mutagens. The test was performed in the absence or in the presence of exogenous metabolic activation system (Aroclor 1254-induced rat liver S9, prepared from adult Sprague Dawley rats, is supplemented with different cofactors (glucose-6-phosphate, NADP- $-\mathrm{Na}^{2}$ ) to a final protein concentration of $2 \mathrm{mg} / \mathrm{mL}$ incubation) to detect indirect and direct mutagenic activity.

Compounds having a nitro function attached to an aromatic or heteroaromatic moiety constitute a group of chemicals biologically active. The reactive forms are metabolically generated through nitroreduction and, in many cases, through oxidative pathways: whereas the oxidative pathways depend on the presence of the cytochrome P450 family of enzymes and occur, therefore, mainly in the liver, nitroreduction is mainly found in bacterial cells [91]. This may explain why nitro compounds are generally strong mutagens in the Salmonella mutagenicity assay, whereas mutagenicity in mammalian cells is not always found for Salmonella-positive nitro compounds [105]. In this context, the standard plate incorporation procedure for detecting his $^{+}$revertants was integrated by nitroreductase deficient strains to better understand compound mechanisms. These bacteria, TA98NR and TA100NR strains, are lacking the "classical" nitroreductase and were isolated as niridazole resistant derivatives of TA98 and TA100 strains, respectively $[106,107]$.

The results of the Salmonella assays are given as mean number of revertants from three independent plates $( \pm S D)$. The data were analysed by using SPSS 11 (SPSS Inc.) Chicago, IL, USA) statistical package. A one-way analysis of the variance test was performed. If a significant $F$ value $(P \leq .05)$ was obtained, the comparison between controls and treated samples was analysed by using Dunnett's $C$-test. A positive result was defined as a reproducible dose-related increase in the number of his ${ }^{+}$revertants. Least squares linear regression analysis was used to calculate specific activity. The activity of the S9 mix and the responsiveness of the tester strains were verified by including appropriate controls into each experiment. Specifically, DMSO ( $80 \mu \mathrm{L} /$ plate), used to redissolve the compounds, was identified as the negative control whereas hycantone (HYC, $75 \mu \mathrm{g} /$ plate) and 2-aminofluorene (2-AF, $2.5 \mu \mathrm{g} / \mathrm{plate}$ ) were used as positive controls without and with $S 9$ mix, respectively [108]. In order to characterize the mutagenic response of NR strains with respect to the parental strains, we examined their sensitivity to 2nitrofluorene (2-NF, $15 \mu \mathrm{g} /$ plate) and furylfuramide (FYFA, $20 \mathrm{ng} /$ plate), whose mutagenicity is substantially lower in nitroreductase deficient than in nitroreductase proficient strains [109].

\subsection{Cytotoxicity Assays in Human Cells}

Short-Term Exposure. Heparin-anticoagulated peripheral blood was obtained by venipuncture from consenting healthy nonsmoker donors as provided by the AVIS (Italian Association of Voluntary Blood Donors). In order to isolate the leukocytes, the blood was maintained at $37^{\circ} \mathrm{C}$ for 5 minuets in an erylysis buffer $\left(155 \mathrm{mM} \mathrm{NH}_{4} \mathrm{Cl}, 5 \mathrm{mM}\right.$
$\mathrm{KHCO}_{3}, 0.005 \mathrm{mM} \mathrm{Na} 2 \mathrm{EDTA}, \mathrm{pH}$ 7.4), centrifuged and washed with PBS, and finally resuspended $\left(\sim 10^{6}\right.$ cells $\left./ \mathrm{mL}\right)$ in RPMI-1640 medium (Gibco). Appropriate amounts of the compounds were added to an Eppendorf tube containing the cell suspension $\left(10^{6}\right.$ cells $)$. The cells were treated for 1 hour at $37^{\circ}$ and then washed twice in PBS. Toxicity was checked immediately after the exposure. Cell survival was determined by the carboxyfluorescein diacetate/ethidium bromide-assay added with Hoechst 33342 (HO). A freshly staining solution ( $15 \mu \mathrm{g} / \mathrm{mL}$ carboxyfluorescein diacetate, $2.5 \mu \mathrm{g} / \mathrm{mL}$ ethidium bromide, $2 \mu \mathrm{g} / \mathrm{mL} \mathrm{HO}$ in PBS) was prepared. $500 \mu \mathrm{l}$ of cell suspension (equivalent to about $5 \times 10^{5}$ cells) was mixed with $10 \mu \mathrm{L}$ of the staining solution, maintained at $37^{\circ} \mathrm{C}$ for 5 minuets. The cells were counted ( 200 cells per data point) under a fluorescent microscope (DAPI/FITC filters): viable leukocytes, whose nucleus is blue-stained by Hoechst 33342, develop a cytoplasmic green fluorescence, while dead cells accumulate ethidium bromide to develop orange fluorescent DNA.

Long-Term Exposure. Immortalized lymphocytes, that is, peripheral blood cells transformed by Epstein-Barr virus in a lymphoblastoid cell line able to actively proliferate (kindly provided by Dr. Dolcetti, (Centro di Riferimento Oncologico, CRO Aviano, Italy), were used for this assay. The cells $\left(2 \times 10^{5} \mathrm{cell} / \mathrm{mL}\right.$ were incubated at $37^{\circ} \mathrm{C}$ in an atmosphere containing $5 \% \mathrm{CO}_{2}$ during 48 hours in a 96 -well plate in the presence of different concentrations of the drug. At the end of the exposure period, cellular suspension was added with the solution reagent $(20 \mu \mathrm{L})$ of CellTiter $96 \mathrm{Aq}_{\text {ueous }}$ One Solution Cell Proliferation Assay (Promega, Madison, WI, USA). After 4 hours incubation, the absorbance at $490 \mathrm{~nm}$ was recorded with a 96-well plate reader (MULTISKAN EX, Thermo Electron Corporation, Vantaa, Finland). The quantity of formazan product as measured by the absorbance at $490 \mathrm{~nm}$ was directly proportional to the number of living cells in culture $[110,111]$.

\subsection{Comet Assay}

2.4.1. Alkaline Assay. The Comet assay was performed, basically according to Singh and coll [102] with minor modifications, on fresh human leukocytes treated as previously described for short-term cytoxicity assay $\left(1\right.$ hour, $37^{\circ} \mathrm{C}$ ) [112]. Cell lysis was carried out at $4^{\circ} \mathrm{C}$ overnight by exposing cells to a buffer containing $2.5 \mathrm{M} \mathrm{NaCl}, 10 \mathrm{mM} \mathrm{Na} 2 \mathrm{EDTA}$, $10 \mathrm{mM}$ Tris- $\mathrm{HCl}, 1 \%$ Triton X-100, and 10\% DMSO, $\mathrm{pH}$ 10. DNA unwinding was achieved over 20 minutes in an electrophoretic alkaline buffer $(1 \mathrm{mM} \mathrm{Na} 2$ EDTA, $300 \mathrm{mM}$ $\left.\mathrm{NaOH}, 0^{\circ} \mathrm{C}, \mathrm{pH}>13\right)$; electrophoresis was then carried out for 20 minutes $(0.78 \mathrm{~V} / \mathrm{cm}, 300 \mathrm{~mA})$ at $0^{\circ} \mathrm{C}$ in the same buffer, followed by neutralisation in $0.4 \mathrm{M}$ Tris- $\mathrm{HCl}, \mathrm{pH}$ 7.5. DNA was stained with $100 \mu \mathrm{L}$ ethidium bromide $(2 \mu \mathrm{g} / \mathrm{mL})$ before the examination at $400 \mathrm{x}$ magnification under a Leika DMLB fluorescence microscope (excitation filter BP 515$560 \mathrm{~nm}$, barrier filter LP $580 \mathrm{~nm}$ ) using an automatic image analysis system (Release 2.1-Sarin, Florence, Italy). The migration distance between the edge of the comet head and end of the tail (total length, TL) provided representative data 
on genotoxic effects. The samples were coded and evaluated blind ( 50 cells per each of two replicate slides per data point). All of the tests were performed at least three times. Ethyl methane sulfonate $(2 \mathrm{mM})$ was used as positive control (TL $=61.03 \pm 4.73 \mu \mathrm{m})$.

\subsubsection{Modified Comet Assay for Detection of Oxidised Bases.} By using endonuclease III (ENDOIII), a DNA glycosylase/endonuclease able to recognise and cleave classes of lesions, specific DNA base modifications such as oxidised pyrimidine bases are converted to strand breaks. These strand breaks can be detected by the comet assay as previously reported. Oxidatively generated damage can be evaluated easily by comparing the DNA migration in enzyme-or buffer-treated samples. The comet assay, with the modification of an extra step after lysis in which DNA is digested with the repair enzyme, was performed according to Collins et al. [113]. Briefly, after cell lysis, the slides were washed three times with the enzyme buffer $(0.1 \mathrm{M}$ $\mathrm{KCl}, 0.5 \mathrm{mM} \mathrm{Na}{ }_{2}$ EDTA, $40 \mathrm{mM}$ HEPES (4-(2-hydroxyethyl)1-piperazineethanesulfonic acid), $0.2 \mathrm{mg} / \mathrm{mL}$ bovine serum albumin, $\mathrm{pH} 8$ with $\mathrm{KOH}$ ) and incubated with ENDOIII in this buffer (or in buffer alone). Hydrogen peroxide $(50 \mu \mathrm{M})$ was used as a positive control ( $\mathrm{TL}=47.13 \pm 2.09 \mu \mathrm{m})$. ENDOIII was isolated from bacteria containing overproducing plasmids (Collin's Laboratory, Rowett Research Institute, Bucksburn, Aberdeen, UK). The enzyme-treated gels reveal alkali labile sites and strand breaks (ALS/SB) and oxidised bases (ALS/SB + OX). Assuming a linear dose response, subtraction of (ALS/SB) from (ALS/SB + OX) gives a measure of oxidised bases.

The SPSS 11 statistical package was used to analyse statistical differences between samples. Statistical differences between controls and treated samples were first determined with the nonparametric Wilcoxon rank-sum test for each experiment. The mean values from the repeated experiments were used in a one-way analysis of variance. Analysis of variance was followed by single or multiple pairwise comparisons. Data were tested for normality and homogeneity of variance. When these criteria were met, the data were compared using Dunnett's version of the $t$-test.

2.5. Micronucleus (MN) Assay. The MN assay was performed using blood samples from healthy, nonsmoking males, as provided by the AVIS (Italian Association of Voluntary Blood Donors). Lymphocytes were separated by Lymphoprep density gradient (Axis-Shield PoC As, Oslo, Norway) and, after two washes in RPMI 1640 medium, cultured at a concentration of $5 \times 10^{5}$ cells $/ \mathrm{mL}$ in RPMI 1640 containing 15\% fetal calf serum (FCS), 2\% v/v KaryoMAX phytohemoagglutinin (Invitrogen LTD, Collegeville, $\mathrm{PE}$, USA), $2 \mathrm{mM}$ L-glutamine, $25 \mathrm{IU} / \mathrm{mL}$ penicillin, and $25 \mu \mathrm{g} / \mathrm{mL}$ streptomycin. The cultures were incubated at $37^{\circ} \mathrm{C}$ in an atmosphere containing $5 \% \mathrm{CO}_{2}$ for 72 hours. Cytochalasin-B was added 44 hours after the start of incubation at a final concentration of $6 \mu \mathrm{g} / \mathrm{mL}$; at 48 hours, the lymphocytes were treated with the different drugs. Sterile DMSO $(1.6 \mu \mathrm{l} / \mathrm{ml})$ was used as a solvent control, and the positive controls were bleomycin $(6 \mu \mathrm{g} / \mathrm{ml})$, ethyl methane
TABle 1: Specific mutagenic activity (revertant increase/dose unit calculated by linear regression analysis on the curve section with response linearity) of NFX, BNZ, and MTZ on different Salmonella strains without or with (+) S9 mix; in brackets: $r^{2}$ value (A). Positive controls are reported for each strain (HYC: hycantone; 2-AF: 2aminofluorene; FYFA: furylfuramide; 2NF: 2-nitrofluorene); mean $( \pm \mathrm{SD})$ of three plates $(\mathrm{B}) .{ }^{*} P<.05$ Dunnett's $C$.

(a)

\begin{tabular}{lccc}
\hline & \multicolumn{3}{c}{ Revertant increase/dose unit } \\
\hline Strain & NFX & BNZ & MTZ \\
TA100 & $80.28(0.99)$ & $64.96(0.98)$ & $5.11(0.98)$ \\
TA100 + & $78.91(0.98)$ & $60.92(0.98)$ & $5.45(0.96)$ \\
TA100NR & $5.18(0.99)$ & $1.75(0.81)$ & $0.37(0.94)$ \\
TA98 & $2.37(0.99)$ & $0.07(0.88)$ & $0.05(0.89)$ \\
TA98 + & $2.06(0.99)$ & $0.10(0.93)$ & $0.08(0.97)$ \\
TA98NR & $0.17(0.94)$ & $0.07(0.93)$ & $0.02(0.79)$ \\
\hline
\end{tabular}

(b)

\begin{tabular}{lcccc}
\hline \multicolumn{5}{c}{ Revertant/plate } \\
\hline Strain & HYC & 2 -AF & FYFA & 2-NF \\
TA100 & $968 \pm 103^{*}$ & $194 \pm 21$ & $1133 \pm 70^{*}$ & \\
TA100 + & & $521 \pm 47^{*}$ & & \\
TA100NR & $785 \pm 97^{*}$ & & $247 \pm 34$ & \\
TA98 & $870 \pm 90^{*}$ & $21 \pm 5$ & $189 \pm 16^{*}$ & $169 \pm 7^{*}$ \\
TA98 + & & $808 \pm 70^{*}$ & & \\
TA98NR & $833 \pm 71^{*}$ & & $25 \pm 4$ & $19 \pm 4$ \\
\hline
\end{tabular}

sulfonate $(120 \mu \mathrm{g} / \mathrm{ml})$, and demecolcine $(0.5 \mu \mathrm{g} / \mathrm{ml})$. Each treatment was tested with cells from two donors, performed in duplicate separate cultures (i.e., four cultures were set up for each treatment). After incubation, the lymphocytes were collected and resuspended in a mild hypotonic solution $(0.075 \mathrm{M} \mathrm{KCl})$ and then added with an ice-cold $5: 3$ acetic acid: methanol solution. After centrifugation (500 g, $10 \mathrm{~min})$, the pellets were resuspended in cold $\left(-20^{\circ} \mathrm{C}\right)$ methanol and maintained at $-20^{\circ} \mathrm{C}$ (at least 24 hours). The cells were 2 fold washed ( $7: 1$ methanol:acetic acid, $-20^{\circ} \mathrm{C}$ ), plated on cold degreased slides, air-dried, and then stained with 2\% v/v Giemsa (Carlo Erba, Milano, Italy). Scoring was done using an Exacta-Optech (Munich, Germany) light microscope at 1000X magnification. Micronuclei were scored according to the criteria described by Fenech [103, 104]. At each dose, at least 1000 binucleated (BN) lymphocytes for each culture were examined for the presence of one or more micronuclei. The MN frequency in $1000 \mathrm{BN}$ cells was then calculated for each treatment. Assays with too few $\mathrm{BN}$ cells to determine the $\mathrm{MN}$ frequency (due to extensive cytotoxic effects) were classified as "toxic." Cellcycle parameters were evaluated by classifying 1000 cells according to the number of nuclei. 1000 cells were counted and scored as mononucleated, binucleated, trinucleated, or tetranucleated and the percentages of the different types of cells were calculated. The nuclear division index (NDI) was calculated by the formula, NDI $=(\mathrm{M} 1+2 \mathrm{M} 2+3 \mathrm{M} 3+$ $4 \mathrm{M} 4) / \mathrm{N}$, where M1 through M4 indicate the number of cells 
with $1 / 4$ nuclei, and $\mathrm{N}$ indicates the total number of cells scored [114].

The statistical analysis of MN frequency was performed using the ${ }^{2} \chi$-test. NDI data were analyzed by Student's $t$-test.

\section{Results}

3.1. Salmonella Plate Incorporation Test. The compounds were investigated on different strains (TA100, TA100NR, TA98, TA98NR) with/without microsomal rat liver fraction (S9 mix). The compounds are more active for base-pair substitution (TA100) than frame-shift induction (TA98). Mutant induction is poorly affected by S9 metabolic activation whereas the nitroreduction process is an essential requirement in order to induce mutagenic effects on Salmonella. On TA100 strain, NFX and BNZ seem to have a similar specific activity (Table 1). MTZ significantly increases the revertant number only at concentrations higher than NFX- and BNZ-effective ones (see Table 1 in Supplementary Material avalible online at doi : 10.1155/2009/463575) and its specific activity is more than ten times lower than NFX and BNZ (Table 1). NFX is the most active on TA98 strain, which shows a low sensitivity against BNZ and MTZ.

\subsection{Human Cells}

\subsubsection{Cytotoxicity Assays}

Short-Term Exposure. For all the compounds, the cellular survival rate did not appear to be affected by the 1hourstreatment in the range of doses used (NFX: 0-348 $\mu \mathrm{M}$; BNZ: 0-348 $\mu \mathrm{M}$; MTZ: $0-585 \mu \mathrm{M})$ when measured immediately after the exposure (data not reported).

Long-Term Exposure. The assay on cultured lymphocytes treated for 48 hours (Figure 1) did not show any significant effects induced by BNZ and MTZ whereas a significant decrease of cell population $(P<.05)$ was observed for NFX at concentration $\geq 56 \mu \mathrm{M}$. These cells need a 48 -hour period for doubling their number. In this context, for evaluating if NFX cytotoxic effect was cell-cycle dependent, the cellular survival was also evaluated after a shorter exposure time (24 hours). In this case, no cytotoxic effect was induced (see Figure 1 in Supplementary Material).

\subsubsection{Genotoxicity Assays}

Comet Assay. The data relative to the primary DNA damage detected on human leukocytes after 1-hours treatment by the comet assay performed at $\mathrm{pH}>13$ (Figure 2(a)) show strong differences among the three drug effectiveness. To improve our understanding on the drug action mechanism, we proceeded to specifically measure BNZ- and NFXinduced oxidative DNA damage by using bacterial repair endonuclease III in the modified comet assay protocol [113] (Figure 2(b)).

BNZ DNA damaging activity was mainly linked to oxidative stress whereas NFX induced DNA base oxidation

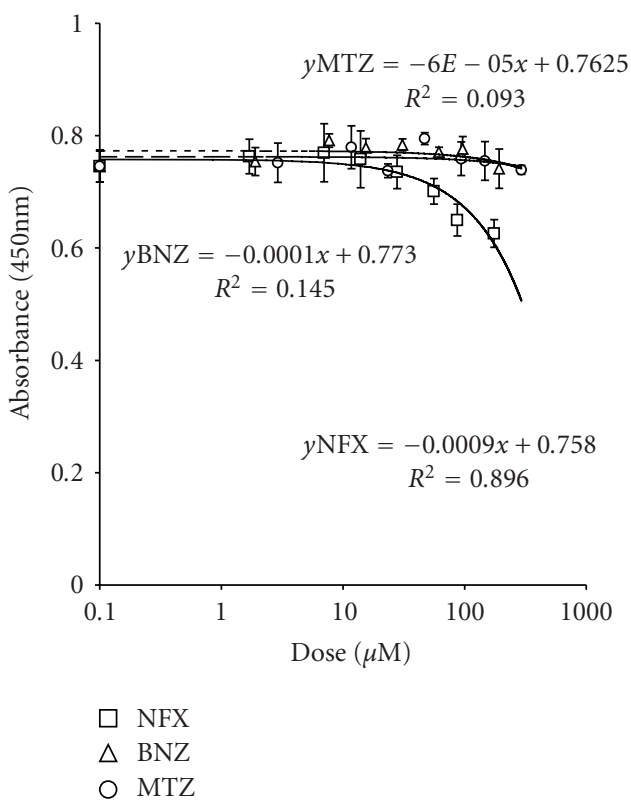

FIGURE 1: Cytotoxic effects induced in immortalized lymphocytes when detected by MTS assay ( 48 hours treatment).

TABle 2: Specific genotoxic activity of NFZ, BNZ, or MTZ on human leukocytes. I: alkaline comet assay; II: comet assay modified with ENDOIII for DNA oxidative damage.

\begin{tabular}{lcc}
\hline & \multicolumn{2}{c}{ DNA migration/dose unit $(\mu \mathrm{m} / \mu \mathrm{M})$} \\
Drug & I & II \\
\hline NFX & $0.0369\left(r^{2}=0.8043\right)$ & $0.106\left(r^{2}=0.9732\right)$ \\
BNZ & $0.3357\left(r^{2}=0.941\right)$ & $0.9077\left(r^{2}=0.8351\right)$ \\
MTZ & $0.0004\left(r^{2}=0.017\right)$ & \\
\hline
\end{tabular}

only at doses $\geq 87 \mu \mathrm{M}$. These findings suggest that NFX could act by a dose-dependent mechanisms: at lower doses, a DNA damage basically independent from the oxidative stress, that is, DNA migration increase detected by the "classic" assay, and an oxidation of DNA bases at higher doses. BNZ specific activity (Table 2) in inducing DNA oxidative damage was about tenfold higher than that of NFX.

MN Assay. On 24-hours treated lymphocytes, the nitrofuran NFX was able to induce a significant increase $(P<.05)$ of MN (Table 3) whereas the two nitroimidazoles (BNZ and MTZ) did not alter MN frequency in the range of doses used (see Table 2 in Supplementary Material). NFX was also the only drug that significantly $(P<.05)$ reduced nuclear division (Table 3 ). The percentages of mono-, bi, tri-, and tetranucleated cells in NFX-treated lymphocytes (see Figure 2 in Supplementary Material) well represents this reduction. Since on 24-hours treated lymphocytes, MTZ and BNZ did not induce any effect, the cells were exposed to the drugs for a longer time (72 hours) as previously reported for MTZ [115]. The data (Table 3) show an increase of MN frequency in cell treated with BNZ, without some decrease 


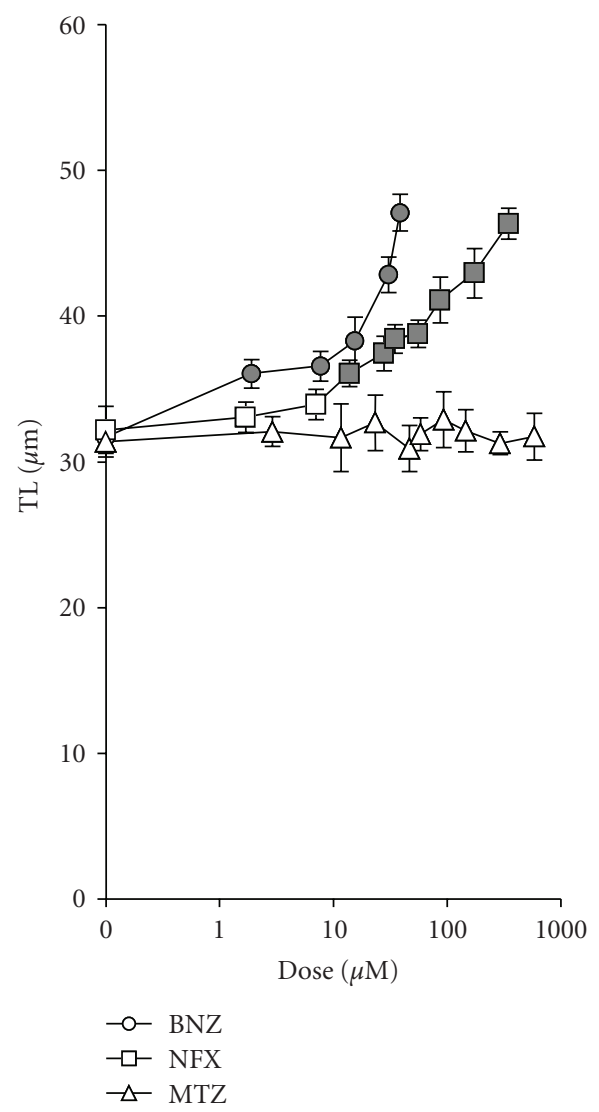

(a)

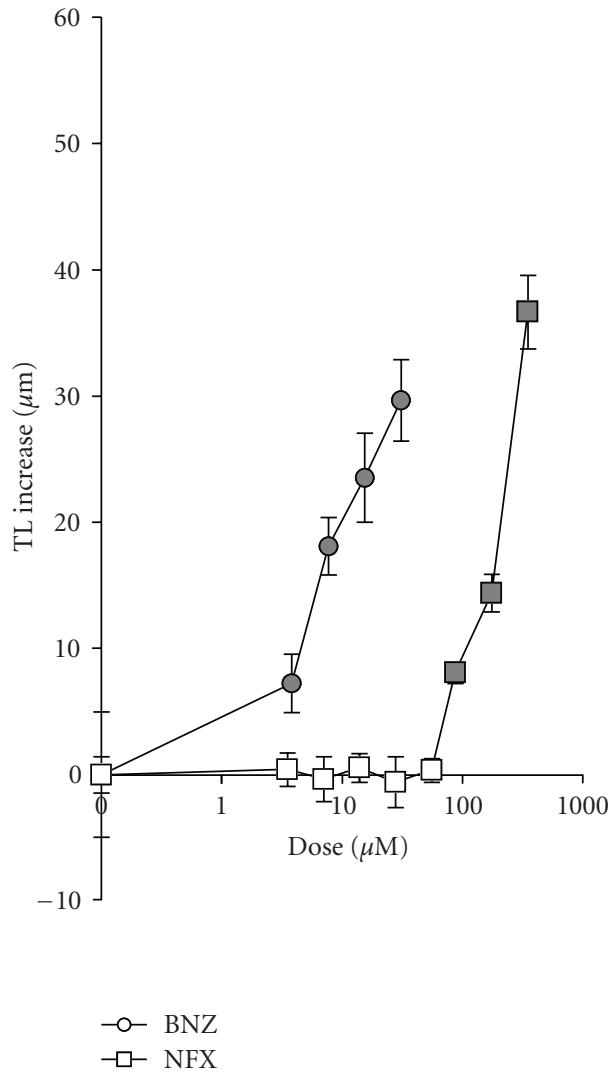

(b)

Figure 2: DNA damage detected in human leukocytes treated $\left(37^{\circ} \mathrm{C}, 1\right.$ hour) with NFX, BNZ, and MTZ. (a): DNA damage is expressed as total migration length (TL, $\mu \mathrm{m}$ ) detected by the alkaline comet assay. (b) Specific oxidatively generated damage to DNA detected by the modified comet assay (ENDO III). DNA oxidative damage is expressed as DNA migration $(\mu \mathrm{m})$ increase with respect to the assay without enzymes. Mean \pm SD of three independent experiments. Filled symbols, $P<.05$ (Dunnett's $\mathrm{C}$ ) with respect to dose 0 .

of nuclear division. On the other hand, the treatment with MTZ did not induce any alteration of both MN and NDI.

\section{Discussion and Conclusions}

The data obtained in this study on the S. typhimurium mutation assay show that the three drugs are more active for basepair substitution than frameshift induction, in agreement with previous reports on nitroheterocycle compounds $[7,19$, $20]$ and are widely dependent from nitroreductase activity. A study [19] reports that the presence of S9 mix decreased BNZ and NFX mutagenicity on Salmonella even if these data were not confirmed [20]. Our data show that microsomal fraction S9 does not or weakly alter the mutagenicity of the tested compounds. The three drugs are differently effective on Salmonella: NFX and BNZ induce in the TA100 strain a significant revertant increase at the lowest used dose whereas MTZ significantly increases the revertant frequency only at higher doses.

The data on Salmonella suggest that these drugs act as direct mutagens, as generally suggested for nitroheterocycle compounds [7]. On the other hand, nitrogroup reduction strongly influences their mutagenic capability. The DNA- reactive forms of nitro compounds may be metabolically generated through nitroreduction [4] and, in some cases, through oxidative pathways [105].

Bacterial mutagenicity assay could give an exaggerated picture of the potency of nitro compounds relative to the effects (mutation and tumour induction) observed in animals $[7,116,117]$. This is probably due to two factors: first, to the greater activity of the nitroreductases in bacteria compared to mammalian cells, and second, to the detoxification reactions and excretion processes which occur in animals. Indeed, these factors produce the difference in sensitivity between pathogen and host, which is the basis for the practical use of nitrocompound derivatives in clinical and veterinary medicine. This resulted in labelling the Salmonella mutagenicity assay as 'not predictive' for this class of compounds $[7,116,117]$. The evaluation of the mutagenic potential of a nitrocompound, therefore, relies strongly on the outcome of tests conducted in mammalian systems.

In previous studies [62], MTZ produced significant dose-related increases of DNA damage, when tested on human lymphocytes in aerobic conditions using the comet assay. Concerning the mechanisms of action, these authors 
TABle 3: Mean frequency of Micronuclei (MN) in binucleated cells and Nuclear Division Index (NDI) in human lymphocytes treated with NFX (24 hours) or BNZ (72 hours) Positive controls:- ethyl methane sulfonate $(1 \mu \mathrm{M}): 15.0 \pm 2.8$; bleomycin $(4 \mu \mathrm{M}): 26.0 \pm 4.0$; demecolcine $(0.9 \mu \mathrm{M}): 65.0 \pm 3.3$.

\begin{tabular}{|c|c|c|c|c|c|c|c|}
\hline \multicolumn{4}{|c|}{ NFX (24 hours) } & \multicolumn{4}{|c|}{ BNZ (72 hours) } \\
\hline $\begin{array}{l}\text { Dose } \\
(\mu \mathrm{M})\end{array}$ & NDI & $\begin{array}{l}\text { NDI } \\
(\%)\end{array}$ & $\begin{array}{c}\mathrm{MN} \\
\left(\times 10^{-3} \mathrm{BN}\right) \\
\end{array}$ & $\begin{array}{l}\text { Dose } \\
(\mu \mathrm{M})\end{array}$ & NDI & $\begin{array}{l}\text { NDI } \\
(\%)\end{array}$ & $\begin{array}{c}\mathrm{MN} \\
\left(\times 10^{-3} \mathrm{BN}\right) \\
\end{array}$ \\
\hline $\mathbf{0}$ & $1.97 \pm 0.10$ & 100 & $2.0 \pm 0.5$ & $\mathbf{0}$ & $1.93 \pm 0.10$ & 100 & $3.5 \pm 0.5$ \\
\hline 1.7 & $1.95 \pm 0.12$ & $99 \pm 6$ & $2.5 \pm 0.5$ & 1.9 & $1.97 \pm 0.10$ & $102 \pm 5$ & $3.0 \pm 0.5$ \\
\hline 3.5 & $1.97 \pm 0.07$ & $100 \pm 4$ & $2.0 \pm 1.0$ & 3.8 & $1.93 \pm 0.11$ & $100 \pm 6$ & $3.5 \pm 1.0$ \\
\hline 7.0 & $1.89 \pm 0.05$ & $96 \pm 3$ & $3.0 \pm 1.0$ & 7.7 & $2.00 \pm 0.07$ & $104 \pm 4$ & $4.0 \pm 1.0$ \\
\hline 13.9 & $1.85 \pm 0.06$ & $94 \pm 3$ & $2.5 \pm 0.5$ & 15.4 & $1.98 \pm 0.06$ & $102 \pm 3$ & $4.0 \pm 1.5$ \\
\hline 27.9 & $1.75 \pm 0.10$ & $89 \pm 5$ & $3.0 \pm 0.5$ & 30.7 & $1.99 \pm 0.05$ & $103 \pm 3$ & $3.5 \pm 1.0$ \\
\hline 55.7 & $1.69 \pm 0.04^{\mathrm{a}}$ & $86 \pm 2^{a}$ & $3.0 \pm 1.0$ & 61.5 & $2.06 \pm 0.07$ & $107 \pm 4$ & $3.0 \pm 0.5$ \\
\hline 87.0 & $1.61 \pm 0.10^{\mathrm{a}}$ & $82 \pm 5^{\mathrm{a}}$ & $4.0 \pm 0.5$ & 96.1 & $2.05 \pm 0.03$ & $106 \pm 2$ & $9.0 \pm 0.5$ \\
\hline 174.0 & $1.43 \pm 0.03^{\mathrm{a}}$ & $73 \pm 2^{\mathrm{a}}$ & $9.0 \pm 1.0$ & 192.1 & $2.00 \pm 0.07$ & $104 \pm 4$ & $13.0 \pm 1.0^{\mathrm{b}}$ \\
\hline 348.1 & $1.41 \pm 0.02^{\mathrm{a}}$ & $72 \pm 1^{\mathrm{a}}$ & $12.0 \pm 1.0^{\mathbf{b}}$ & 384.2 & $1.93 \pm 0.10$ & $100 \pm 6$ & $16.5 \pm 0.5^{b}$ \\
\hline
\end{tabular}

${ }^{\text {a } P}<.05$ Student's $t$-test; ${ }^{\mathrm{b}} P<.05^{2} \chi$-test

proposed that MTZ was able to induce DNA damage through the so-called futile cycle that is, one electron reduction of the drug leads to the production of nitroradical anions which are oxidised in the presence of oxygen and may generate reactive oxygen species (ROS). On the other hand, in our experiments, MTZ did not induce any significant increase on DNA migration up to $585 \mu \mathrm{M}$, that is, about tenfolds higher $(100 \mu \mathrm{g} / \mathrm{ml})$ than plasmatic concentration in MTZ-treated patients $(8-13 \mu \mathrm{g} / \mathrm{ml})$. In actual fact, conflicting results are reported in literature regarding MTZ genotoxicity in mammal cells $[33,34,57,60-66,68,71-81]$. The lack of any significant cytotoxic or genotoxic effects induced by MTZ in our experimental conditions on human cells suggests that MTZ biological activity could be strictly dependent on anaerobic conditions $[81,118]$. In fact, Korbelik and Horvat [67] observed clastogenic effects only in hypoxic mammalian cells: in this condition, the toxic effect of a reduction of the nitro group should be similar to those in microorganisms living under anaerobic conditions.

In agreement with some previous reports [27, 28, 37-39], our findings confirmed that BNZ and NFX are able to induce significant genotoxic effects on human cells. Furthermore, the lowest BNZ and NFX doses able to induce DNA damage detectable by the comet assay are in the range of plasmatic concentrations in patients therapeutically treated with these two nitro compounds.

The two drugs are reported to produce similar free radicals $[4,14]$. However, in our experimental conditions, the behaviour of BNZ and NFX in inducing DNA oxidative damage suggests different mechanisms of action for the two compounds. Specifically, the analysis of DNA oxidative damage data shows that BNZ mainly acts through free radical species production whereas dose-depending mechanisms could be suggested for NFX. Some differences between the nitrofuran and the nitroimidazol were also found in $\mathrm{MN}$ test: shorter exposure time is necessary for NFX than for BNZ (24 hours versus 72 hours) to induce a significant genetic damage.
Even cytotoxicity data suggest specific action mechanisms for the three compounds. Whereas no effect was observed on the survival of nondividing cells up to the highest doses used for all the drugs, NFX was able to induce cytotoxic effects on actively proliferating cells at $56 \mu \mathrm{M}$.

NFX and BMZ genotoxicity was detected by both comet and $\mathrm{MN}$ assay, even if in different ranges of concentrations. Comet assay showed significantly increased DNA damage at lower concentrations, but these lower concentrations were not able to increase the chromosomal damage detected by $\mathrm{MN}$ assay. The discrepancies between the results obtained by the Comet and $\mathrm{MN}$ tests, as reported in other investigations $[119,120]$, are probably caused by the nature of these two assays. The Comet detects primary DNA lesions resulting from the balance of DNA damage and repair mechanisms. The MN test detects DNA damage that has been transformed to structural and numerical chromosome alterations and reveals fixed DNA lesions or unrepairable aneugenic effects.

A distinguishing property among the three compounds is their reduction potential. The 5-nitroimidazol derivative (MTZ) shows comparatively low reduction potential: it can be reduced to the corresponding amino derivative only under anaerobic conditions and its spectrum of activity can result limited to anaerobic or facultative anaerobic bacteria. On the other hand, both the antitrypanosomal drugs, NFX and BNZ, may not only lead to cellular damage of the infective agent but also interact with the DNA of mammalian cells by the formation of free radicals and redox cycling.

In conclusion, the genotoxic profile of MTZ, NFX, and BNZ is further defined from our findings. MTZ therapeutic use could represent a genotoxic hazard only for the host cells in anoxic conditions. The high DNA damaging potential of NFX and BNZ on mammalian cells, together with other known severe side-effects on patients and low effectiveness in the second stage of the Chagas' disease, call for new safer drugs against Trypanosoma infection. 


\section{Acknowledgments}

This work was supported by Grants from FIL, University of Parma, Italy, and FAPESP, São Paulo, Brazil. The authors would like to thank Mrs. Antonietta Cirasolo (University of Parma) for technical support.

\section{References}

[1] J. A. Upcroft, R. W. Campbell, K. Benakli, P. Upcroft, and P. Vanelle, "Efficacy of new 5-nitroimidazoles against metronidazole-susceptible and- resistant Giardia, Trichomonas, and Entamoeba spp," Antimicrobial Agents and Chemotherapy, vol. 43, no. 1, pp. 73-76, 1999.

[2] J. Chopra, "Antibiotics," in Encyclopedia of Life Sciences/(C), Macmillan, Nature, New York, NY, USA, 2002.

[3] P. J. Jenks and D. I. Edwards, "Metronidazole resistance in Helicobacter pylori," International Journal of Antimicrobial Agents, vol. 19, no. 1, pp. 1-7, 2002.

[4] W. Raether and H. Hänel, "Nitroheterocyclic drugs with broad spectrum activity," Parasitology Research, vol. 90, supplement 1, pp. S19-S39, 2003.

[5] J. A. Squella, M. E. Letelier, L. Lindermeyer, and L. J. NuñezVergara, "Redox behaviour of nifuroxazide: generation of the one-electron reduction product," Chemico-Biological Interactions, vol. 99, no. 1-3, pp. 227-238, 1996.

[6] J. R. Pires, C. Saito, S. L. Gomes, A. M. Giesbrecht, and A. T.-D. Amaral, "Investigation of 5-nitrofuran derivatives: synthesis, antibacterial activity, and quantitative structureactivity relationships," Journal of Medicinal Chemistry, vol. 44, no. 22, pp. 3673-3681, 2001.

[7] D. R. McCalla, "Mutagenicity of nitrofuran derivatives: review," Environmental Mutagenesis, vol. 5, no. 5, pp. 745765, 1983.

[8] J. Pépin, F. Milord, B. Mpia, et al., "An open clinical trial of nifurtimox for arseno-resistant Trypanosoma brucei gambiense sleeping sickness in central Zaire," Transactions of the Royal Society of Tropical Medicine and Hygiene, vol. 83, no. 4, pp. 514-517, 1989.

[9] J. Pépin, F. Milord, F. Meurice, L. Ethier, L. Loko, and B. Mpia, "High-dose nifurtimox for arseno-resistant Trypanosoma brucei gambiense sleeping sickness: an open trial in central Zaire," Transactions of the Royal Society of Tropical Medicine and Hygiene, vol. 86, no. 3, pp. 254-256, 1992.

[10] S. Bisser, F.-X. N'Siesi, V. Lejon, et al., "Equivalence trial of melarsoprol and nifurtimox monotherapy and combination therapy for the treatment of second-stage Trypanosoma brucei gambiense sleeping sickness," Journal of Infectious Diseases, vol. 195, no. 3, pp. 322-329, 2007.

[11] M. Faundez, L. Pino, P. Letelier, et al., "Buthionine sulfoximine increases the toxicity of nifurtimox and benznidazole to Trypanosoma cruzi," Antimicrobial Agents and Chemotherapy, vol. 49, no. 1, pp. 126-130, 2005.

[12] J. A. Castro and E. G. Diaz de Toranzo, "Toxic effects of nifurtimox and benznidazole, two drugs used against American trypanosomiasis (Chagas' disease)," Biomedical and Environmental Sciences, vol. 1, no. 1, pp. 19-33, 1988.

[13] J. A. Castro, "Contributions of toxicology to the problem of Chagas' disease (American trypanosomiasis). A year 2000 update," Biomedical and Environmental Sciences, vol. 13, no. 4, pp. 271-279, 2000.

[14] R. Docampo and S. N. Moreno, "Biochemical toxicology of antiparasitic compounds used in the chemotherapy and chemoprophylaxis of American trypanosomiasis (Chagas' disease)," Reviews in Biochemical Toxicology, vol. 7, pp. 159204, 1985.

[15] E. G. D. de Toranzo, D. M. Herrera, and J. A. Castro, "Rat liver nuclear nifurtimox nitroreductase activity," Research Communications in Molecular Pathology and Pharmacology, vol. 98, no. 3, pp. 249-254, 1997.

[16] P. H. Carrizo, M. Dubin, and A. O. M. Stoppani, "Generation of peroxinitrite by nifurtimox in rat liver microsomes," Biocell, vol. 24, supplement, p. 63, 2000.

[17] M. M. de Mecca, E. G. Diaz, and J. A. Castro, "Nifurtimox biotransformation to reactive metabolites or nitrite in liver subcellular fractions and model systems," Toxicology Letters, vol. 136, no. 1, pp. 1-8, 2002.

[18] T. Ohnishi, Y. Ohashi, K. Nozu, and S. Inoki, "Mutagenicity of nifurtimox in Escherichia coli," Mutation Research, vol. 77, no. 3, pp. 241-244, 1980.

[19] R. Nagel and I. Nepomnaschy, "Mutagenicity of 2 antiChagasic drugs and their metabolic deactivation," Mutation Research, vol. 117, no. 3-4, pp. 237-242, 1983.

[20] R. C. C. Ferreira and L. C. S. Ferreira, "Mutagenicity of nifurtimox and benznidazole in the Salmonella/microsome assay," Brazilian Journal of Medical and Biological Research, vol. 19, no. 1, pp. 19-25, 1986.

[21] E. Alejandre-Durán, R. M. Claramunt, D. Sanz, M. J. Vilaplana, P. Molina, and C. Pueyo, "Study on the mutagenicity of nifurtimox and eight derivatives with the L-arabinose resistance test of Salmonella typhimurium," Mutation Research, vol. 206, no. 2, pp. 193-200, 1988.

[22] M. E. Melo and L. C. Ferreira, "Screening the mutagenic activities of commonly used antiparasite drugs by the Simultes, a simplified Salmonella/microsome plate incorporation assay," Revista do Instituto de Medicina Tropical de São Paulo, vol. 32, pp. 269-274, 1990.

[23] J. Jurado and C. Pueyo, "Role of classical nitroreductase and $O$-acetyltransferase on the mutagenicity of nifurtimox and eight derivatives in Salmonella typhimurium," Environmental and Molecular Mutagenesis, vol. 26, no. 1, pp. 86-93, 1995.

[24] M.-C. Chung, R. V. Carvalho Güido, T. Favarato Martinelli, et al., "Synthesis and in vitro evaluation of potential antichagasic hydroxymethylnitrofurazone (NFOH-121): a new nitrofurazone prodrug," Bioorganic and Medicinal Chemistry, vol. 11, no. 22, pp. 4779-4783, 2003.

[25] R. C. C. Ferreira, M. E. B. de Melo, M. A. Moraes Jr., and L. C. S. Ferreira, "Evaluation of genotoxic activity in the blood and urine of guinea pigs treated with nifurtimox and benznidazole," Brazilian Journal of Medical and Biological Research, vol. 21, no. 5, pp. 1069-1077, 1988.

[26] A. A. Moraga and U. Graf, "Genotoxicity testing of antiparasitic nitrofurans in the Drosophila wing somatic mutation and recombination test," Mutagenesis, vol. 4, no. 2, pp. 105110, 1989.

[27] N. B. Gorla and J. A. Castro, "Micronucleus formation in bone marrow of mice treated with nifurtimox or benznidazole," Toxicology Letters, vol. 25, no. 3, pp. 259-263, 1985.

[28] N. B. Gorla, "Sister-chromatid exchange in spleenic lymphocytes of mice after exposure to nifurtimox or benznidazole," Mutation Research, vol. 188, no. 2, pp. 129-133, 1987.

[29] N. B. Gorla, O. S. Ledesma, G. P. Barbieri, and I. B. Larripa, "Thirteen fold increase of chromosomal aberrations non-randomly distributed in Chagasic children treated with nifurtimox," Mutation Research, vol. 224, no. 2, pp. 263-267, 1989.

[30] A. R. L. Teixeira, R. Silva, E. Cunha Neto, J. M. Santana, and L. V. Rizzo, "Malignant, non-Hodgkin's lymphomas in 
Trypanosoma cruzi-infected rabbits treated with nitroarenes," Journal of Comparative Pathology, vol. 103, no. 1, pp. 37-48, 1990.

[31] A. R. L. Teixeira, M. A. Calixto, and M. L. Teixeira, "Chagas' disease: carcinogenic activity of the antitrypanosomal nitroarenes in mice," Mutation Research, vol. 305, no. 2, pp. 189-196, 1994.

[32] M. J. Iatropoulos, C. X. Wang, E. von Keutz, and G. M. Williams, "Assessment of chronic toxicity and carcinogenicity in an accelerated cancer bioassay in rats of nifurtimox, an antitrypanosomiasis drug," Experimental and Toxicologic Pathology, vol. 57, no. 5-6, pp. 397-404, 2006.

[33] R. C. C. Ferreira and L. C. S. Pereira, "Avaliação do potencial mutagênico-cancerígeno de fármacos pelo ensaio salmonella/fração microssomal: I. Mutagenecidade de drogas anti-Trypanosoma cruzi," Ciência e Cultura, vol. 38, pp. 696702, 1986.

[34] R. C. Knight, I. M. Skolimowski, and D. I. Edwards, "The interaction of reduced metronidazole with DNA," Biochemical Pharmacology, vol. 27, no. 17, pp. 2089-2093, 1978.

[35] C. E. Voogd, J. J. van der Stel, and J. J. Jacobs, "The mutagenic action of nitroimidazoles-II: effects of 2 nitroimidazoles," Mutation Research, vol. 31, no. 3, pp. 149-152, 1975.

[36] R. C. C. Ferreira, U. Schwarz, and L. C. S. Ferreira, "Activation of anti-Trypanosoma cruzi drugs to genotoxic metabolites promoted by mammalian microsomal enzymes," Mutation Research, vol. 204, no. 4, pp. 577-583, 1988.

[37] P. R. Moya and G. T. Trombotto, "Enfermedade de Chagas: efecto clastogenico de nifurtimox y benznidazol en niños," Medicina, vol. 48, pp. 487-491, 1988.

[38] Z. G. M. Lacava and H. Luna, "The anticlastogenic effect of tocopherol in peritoneal macrophages of benznidazoletreated and ovariectomized mice," Mutation Research, vol. 305, no. 2, pp. 145-150, 1994.

[39] S. J. Santos, C. S. Takahashi, and A. T. Natarajan, "Cytogenetic effects of the antichagasic benznidazole on human cells in vitro," Mutation Research, vol. 320, no. 4, pp. 305-314, 1994.

[40] E. N. Kaneshima and M. A. A. de Castro-Prado, "Benznidazole-induced genotoxicity in diploid cells of Aspergillus nidulans," Memorias do Instituto Oswaldo Cruz, vol. 100, no. 3, pp. 325-329, 2005.

[41] A. Buschini, F. Giordani, C. N. de Albuquerque, et al., "Trypanocidal nitroimidazole derivatives: relationships among chemical structure and genotoxic activity," Biochemical Pharmacology, vol. 73, no. 10, pp. 1537-1547, 2007.

[42] N. Gorla, M. I. Diaz Gomez, and J. A. Castro, "Interaction of benznidazole reactive metabolites with rat liver deoxyribonucleic acid and nuclear proteins," Archives Internationales de Pharmacodynamie et de Therapie, vol. 280, no. 1, pp. 2231, 1986.

[43] A. Zahoor, M. V. M. Lafleur, R. C. Knight, H. Loman, and D. I. Edwards, "DNA damage induced by reduced nitroimidazole drugs," Biochemical Pharmacology, vol. 36, no. 19, pp. 3299-3304, 1987.

[44] S. C. Souza, C. S. Takahashi, and J. S. da Silva, "Evaluation of the mutagenic potential of the antichagasic drug Rochagan in healthy and Chagasic rodents," Mutation Research, vol. 259, no. 2, pp. 139-145, 1991.

[45] M. Müller, "Mode of action of metronidazole on anaerobic bacteria and protozoa," Surgery, vol. 93, no. 1, pp. 165-171, 1983.
[46] J. Samuelson, "Why metronidazole is active against both bacteria and parasites," Antimicrobial Agents and Chemotherapy, vol. 43, no. 7, pp. 1533-1541, 1999.

[47] K. M. Land and P. J. Johnson, "Molecular mechanisms underlying metronidazole resistance in trochomonads," Experimental Parasitology, vol. 87, no. 3, pp. 305-308, 1997.

[48] R. M. J. Ings, J. A. McFadzean, and W. E. Ormerod, "The mode of action of metronidazole in Trichomonas vaginalis and other micro organisms," Biochemical Pharmacology, vol. 23, no. 9, pp. 1421-1429, 1974.

[49] P. Hrelia, L. Murelli, M. Paolini, and G. Cantelli-Forti, "In vivo protective role of antioxidants against genotoxicity of metronidazole and azanidazole," Drugs under Experimental and Clinical Research, vol. 13, no. 9, pp. 577-583, 1987.

[50] C. Mallikarjuna Rao, A. Ghosh, C. Raghothama, and K. L. Bairy, "Does metronidazole reduce lipid peroxidation in burn injuries to promote healing?" Burns, vol. 28, no. 5, pp. 427-429, 2002.

[51] S. Narayanan, A. Hünerbein, M. Getie, A. Jäckel, and R. H. H. Neubert, "Scavenging properties of metronidazole on free oxygen radicals in a skin lipid model system," Journal of Pharmacy and Pharmacology, vol. 59, no. 8, pp. 1125-1130, 2007.

[52] M. A. Pélissier, P. Marteau, and P. Pochart, "Antioxidant effects of metronidazole in colonic tissue," Digestive Diseases and Sciences, vol. 52, no. 1, pp. 40-44, 2007.

[53] E. J. T. Chrystal, R. L. Koch, M. A. McLafferty, and P. Goldman, "Relationship between metronidazole metabolism and bactericidal activity," Antimicrobial Agents and Chemotherapy, vol. 18, pp. 566-573, 1980.

[54] W. T. Speck, A. B. Stein, and H. S. Rosenkranz, "Mutagenicity of metronidazole: presence of several active metabolites in human urine," Journal of the National Cancer Institute, vol. 56, no. 2, pp. 283-284, 1976.

[55] T. H. Connor, M. Stoeckel, J. Evrard, and M. S. Legator, "The contribution of metronidazole and two metabolites to the mutagenic activity detected in urine of treated humans and mice," Cancer Research, vol. 37, no. 2, pp. 629-633, 1977.

[56] N. F. LaRusso, M. Tomasz, M. Müller, and R. Lipman, "Interaction of metronidazole with nucleic acids in vitro," Molecular Pharmacology, vol. 13, no. 5, pp. 872-882, 1977.

[57] H. C. Wulf, "Sister chromatid exchanges in lymphocytes treated with metronidazole. Preliminary communication," Danish Medical Bulletin, vol. 27, no. 1, pp. 38-40, 1980.

[58] L. D. Dale, T. M. Dyson, D. A. Tocher, J. H. Tocher, and D. I. Edwards, "Studies on DNA damage and induction of SOS repair by novel multifunctional bioreducible compounds. I. A metronidazole adduct of dirhodium (II) tetraacetate," Anti-Cancer Drug Design, vol. 4, no. 4, pp. 295-302, 1989.

[59] A. Martelli, A. Allavena, L. Robbiano, F. Mattioli, and G. Brambilla, "Comparison of the sensitivity of human and rat hepatocytes to the genotoxic effects of metronidazole," Pharmacology and Toxicology, vol. 66, no. 5, pp. 329-334, 1990.

[60] M. Reitz, M. Rumpf, and R. Knitza, "DNA single strand-breaks in lymphocytes after metronidazole therapy," Arzneimittel-Forschung, vol. 41, no. 2, pp. 155-156, 1991.

[61] M. Reitz, M. Rumpf, and R. Knitza, "Metronidazole induces DNA strand-breaks in cultures of human lymphocytes and phytohemagglutinin-stimulated human lymphocytes," Arzneimittel-Forschung, vol. 41, no. 1, pp. 65-69, 1991.

[62] J. L. Ré, M. P. De Méo, M. Laget, et al., "Evaluation of the genotoxic activity of metronidazole and dimetridazole in 
human lymphocytes by the comet assay," Mutation Research, vol. 375, no. 2, pp. 147-155, 1997.

[63] D. Menéndez, E. Rojas, L. A. Herrera, et al., "DNA breakage due to metronidazole treatment," Mutation Research, vol. 478, no. 1-2, pp. 153-158, 2001.

[64] G. Rodriguez Ferreiro, L. Cancino Badías, M. Lopez-Nigro, et al., "DNA single strand breaks in peripheral blood lymphocytes induced by three nitroimidazole derivatives," Toxicology Letters, vol. 132, no. 2, pp. 109-115, 2002.

[65] J. M. Ornelas-Aguirre, B. C. Gómez-Meda, A. L. ZamoraPerez, M. L. Ramos-Ibarra, C. M. Batista-González, and G. M. Zúñiga-González, "Micronucleus induction by metronidazole in rat vaginal mucosa," Environmental and Molecular Mutagenesis, vol. 47, no. 5, pp. 352-356, 2006.

[66] B. Lambert, A. Lindblad, and U. Ringborg, "Absence of genotoxic effects of metronidazole and two of its urinary metabolites on human lymphocytes in vitro," Mutation Research, vol. 67, no. 3, pp. 281-287, 1979.

[67] M. Korbelik and D. Horvat, "The mutagenicity of nitroaromatic drugs. Effect of metronidazole after incubation in hypoxia in vitro," Mutation Research, vol. 78, no. 2, pp. 201207, 1980.

[68] B. Hartley-Asp, "Metronidazole: absence of mammalian cytogenicity," Scandinavian Journal of Infectious Diseases, vol. 13, supplement 26, pp. 72-74, 1981.

[69] J. Dayan, M. C. Crajer, and S. Deguingand, "Mutagenic activity of 4 active-principle forms of pharmaceutical drugs. Comparative study in the Salmonella typhimurium microsome test, and the HGPRT and $\mathrm{Na}^{+} / \mathrm{K}^{+}$ATPase systems in cultured mammalian cells," Mutation Research, vol. 102, no. 1, pp. 1-12, 1982.

[70] J. S. Mahood and R. L. Wilson, "Metronidazole (Flagyl): lack of induction of sister-chromatid exchanges in CHO-K1 cells," Mutation Research, vol. 122, no. 2, pp. 187-192, 1983.

[71] M. Konopacka, E. Grzybowska, and J. Michalska, "Lack of genotoxic activity of metronidazole and P1 derivative in two eukaryotic tests," Polish Journal of Pharmacology and Pharmacy, vol. 42, no. 5, pp. 471-477, 1990.

[72] R. Fahrig and M. Engelke, "Reinvestigation of in vivo genotoxicity studies in man. I. No induction of DNA strand breaks in peripheral lymphocytes after metronidazole therapy," Mutation Research, vol. 395, no. 2-3, pp. 215-221, 1997.

[73] F. Mitelman, B. Hartley-Asp, and B. Ursing, "Chromosome aberrations and metronidazole," The Lancet, vol. 2, no. 7989, p. 802, 1976.

[74] G. Elizondo, M. E. Gonsebatt, A. M. Salazar, et al., "Genotoxic effects of metronidazole," Mutation Research, vol. 370, no. 2, pp. 75-80, 1996.

[75] R. J. Trzos, G. L. Petzold, M. N. Brunden, and J. A. Swenberg, "The evaluation of sixteen carcinogens in the rat using the micronucleus test," Mutation Research, vol. 58, no. 1, pp. 7986, 1978.

[76] C. E. Voogd, J. J. van der Stel, and J. J. Jacobs, "The mutagenic action of nitroimidazoles. IV: a comparison of the mutagenic action of several nitroimidazoles and some imidazoles," Mutation Research, vol. 66, no. 3, pp. 207-221, 1979.

[77] F. Mitelman, B. Strömbeck, B. Ursing, O. Nordle, and B. Hartley-Asp, "Metronidazole exhibits no clastogenic activity in a double-blind cross-over study on Crohn's patients," Hereditas, vol. 96, no. 2, pp. 279-286, 1982.
[78] S. B. Neal and G. S. Probst, "Chemically-induced sisterchromatid exchange in vivo in bone marrow of Chinese hamsters. An evaluation of 24 compounds," Mutation Research, vol. 113, no. 1, pp. 33-43, 1983.

[79] L. Pylkkänen and J. Lähdetie, "Sperm abnormality assay of metronidazole and tinidazole," Mutation Research, vol. 140, no. 2-3, pp. 137-140, 1984.

[80] P. Ostrosky-Wegman, I. Lares Asseff, P. Santiago, G. Elizondo, and R. Montero, "Metronidazole hprt mutation induction in sheep and the relationship with its elimination rate," Mutation Research, vol. 307, no. 1, pp. 253-259, 1994.

[81] L. Dobías, M. Cerna, P. Rössner, and R. Srám, "Genotoxicity and carcinogenicity of metronidazole," Mutation Research, vol. 317, no. 3, pp. 177-194, 1994.

[82] IARC, Evaluation of Carcinogenic Risk to Humans, International Agency for Research on Cancer, Lyon, France, 1987.

[83] M. Rustia and P. Shubik, "Induction of lung tumors and malignant lymphomas in mice by metronidazole," Journal of the National Cancer Institute, vol. 48, no. 3, pp. 721-729, 1972.

[84] M. Rustia and P. Shubik, "Experimental induction of hepatomas, mammary tumors, and other tumors with metronidazole in noninbred Sas:MRC(WI)BR rats," Journal of the National Cancer Institute, vol. 63, no. 3, pp. 863-868, 1979.

[85] S. M. Cohen, F. Ertürk, A. M. Von Esch, A. J. Crovetti, and G. T. Bryan, "Carcinogenicity of 5 nitrofurans, 5 nitroimidazoles, 4 nitrobenzenes, and related compounds," Journal of the National Cancer Institute, vol. 51, no. 2, pp. 403-417, 1973.

[86] A. Cavaliere, M. Bacci, A. Amorosi, M. Del Gaudio, and R. Vitali, "Induction of lung tumors and lymphomas in BALB/c mice by metronidazole," Tumori, vol. 69, no. 5, pp. 379-382, 1983.

[87] M. Chacko and S. V. Bhide, "Carcinogenicity, perinatal carcinogenicity and teratogenicity of low dose metronidazole (MNZ) in Swiss mice," Journal of Cancer Research and Clinical Oncology, vol. 112, no. 2, pp. 135-140, 1986.

[88] A. Bendesky, D. Menéndez, and P. Ostrosky-Wegman, "Is metronidazole carcinogenic?" Mutation Research, vol. 511, no. 2, pp. 133-144, 2002.

[89] J. R. Coura and S. L. de Castro, "A critical review on Chagas disease chemotherapy," Memorias do Instituto Oswaldo Cruz, vol. 97, no. 1, pp. 3-24, 2002.

[90] J. A. Urbina, "Specific treatment of Chagas disease: current status and new developments," Current Opinion in Infectious Diseases, vol. 14, no. 6, pp. 733-741, 2001.

[91] H. Cerecetto and M. González, "Chemotherapy of Chagas' disease: status and new developments," Current Topics in Medicinal Chemistry, vol. 2, no. 11, pp. 1187-1213, 2002.

[92] L. V. Kirchhoff, "Changing epidemiology and approaches to therapy for Chagas disease," Current Infectious Disease Reports, vol. 5, no. 1, pp. 59-65, 2003.

[93] J. A. Urbina and R. Docampo, "Specific chemotherapy of Chagas disease: controversies and advances," Trends in Parasitology, vol. 19, no. 11, pp. 495-501, 2003.

[94] J. A. Castro, M. M. de Mecca, and L. C. Bartel, "Toxic side effects of drugs used to treat Chagas' disease (American trypanosomiasis)," Human and Experimental Toxicology, vol. 25, no. 8, pp. 471-479, 2006.

[95] M. L. M. Gonzales, L. F. Dans, and E. G. Martinez, "Antiamoebic drugs for treating amoebic colitis," Cochrane Database of Systematic Reviews, vol. 15, no. 2, Article ID CD006085, 2009. 
[96] L. Bujanda and A. Cosme, "Diarrea asociada a Clostridium difficile," Gastroenterología y Hepatología, vol. 32, no. 1, pp. 48-56, 2009.

[97] L. V. McFarland, "Renewed interest in a difficult disease: Clostridium difficile infections-epidemiology and current treatment strategies," Current Opinion in Gastroenterology, vol. 25, no. 1, pp. 24-35, 2009.

[98] D. A. Leffler and J. T. Lamont, "Treatment of Clostridium difficile-associated disease," Gastroenterology, vol. 136, no. 6, pp. 1899-1912, 2009.

[99] K. Abba, R. Sinfield, C. A. Hart, and P. Garner, "Antimicrobial drugs for persistent diarrhoea of unknown or non-specific cause in children under six in low and middle income countries: systematic review of randomized controlled trials," BMC Infectious Diseases, vol. 9, article 24, 2009.

[100] H. S. Rosenkranz Jr. and R. Mermelstein, "Mutagenicity and genotoxicity of nitroarenes. All nitro-containing chemicals were not created equal," Mutation Research, vol. 114, no. 3, pp. 217-267, 1983.

[101] D. M. Maron and B. N. Ames, "Revised methods for the Salmonella mutagenicity test," Mutation Research, vol. 113, no. 3-4, pp. 173-215, 1983.

[102] N. P. Singh, M. T. McCoy, R. R. Tice, and E. L. Schneider, "A simple technique for quantitation of low levels of DNA damage in individual cells," Experimental Cell Research, vol. 175, no. 1, pp. 184-191, 1988.

[103] M. Fenech, "The cytokinesis-block micronucleus technique," in Technologies for Detection of DNA Damage and Mutations, G. P. Pfeifer, Ed., pp. 25-36, Plenum Press, New York, NY, USA, 1996.

[104] M. Fenech, “The in vitro micronucleus technique," Mutation Research, vol. 455, no. 1-2, pp. 81-95, 2000.

[105] W. Suter, A. Hartmann, F. Poetter, P. Sagelsdorff, P. Hoffmann, and H.-J. Martus, "Genotoxicity assessment of the antiepileptic drug AMP397, an Ames-positive aromatic nitro compound," Mutation Research, vol. 518, no. 2, pp. 181-194, 2002.

[106] H. S. Rosenkranz and W. T. Speck, "Activation of nitrofuran (toin) to a mutagen by rat liver nitroreductase," Biochemical Pharmacology, vol. 25, pp. 1555-1556, 1976.

[107] E. C. McCoy, E. J. Rosenkranz, L. A. Petrullo, and H. S. Rosenkranz, "Frameshift mutations: relative roles of simple intercalation and of adduct formation," Mutation Research, vol. 90, no. 1, pp. 21-30, 1981.

[108] D. Gatehouse, S. Haworth, T. Cebula, et al., "Recommendations for the performance of bacterial mutation assays," Mutation Research, vol. 312, no. 3, pp. 217-233, 1994.

[109] M. Yamada, J. J. Espinosa-Aguirre, M. Watanabe, K. Matsui, T. Sofuni, and T. Nohmi, "Targeted disruption of the gene encoding the classical nitroreductase enzyme in Salmonella typhimurium Ames test strains TA1535 and TA1538," Mutation Research, vol. 375, no. 1, pp. 9-17, 1997.

[110] A. H. Cory, T. C. Owen, J. A. Barltrop, and J. G. Cory, "Use of an aqueous soluble tetrazolium/formazan assay for cell growth assays in culture," Cancer Communications, vol. 3, no. 7, pp. 207-212, 1991.

[111] T. L. Riss and R. A. Moravec, "Use of multiple assay endpoints to investigate the effects of incubation time, dose of toxin, and plating density in cell-based cytotoxicity assays," Assay and Drug Development Technologies, vol. 2, no. 1, pp. 51-62, 2004.

[112] R. R. Tice, E. Agurell, D. Anderson, et al., "Single cell gel/comet assay: guidelines for in vitro and in vivo genetic toxicology testing," Environmental and Molecular Mutagenesis, vol. 35, no. 3, pp. 206-221, 2000.

[113] A. R. Collins, V. L. Dobson, M. Dušinská, G. Kennedy, and R. Štětina, "The comet assay: what can it really tell us?" Mutation Research, vol. 375, no. 2, pp. 183-193, 1997.

[114] D. A. Eastmond and J. D. Tucker, "Identification of aneuploidy-inducing agents using cytokinesis-blocked human lymphocytes and an antikinetochore antibody," Environmental and Molecular Mutagenesis, vol. 13, no. 1, pp. 34-43, 1989.

[115] M. D. Mudry, M. Carballo, M. Labal de Vinuesa, M. G. Cid, and I. Larripa, "Mutagenic bioassay of certain pharmacological drugs: III. Metronidazole (MTZ)," Mutation Research, vol. 305, no. 2, pp. 127-132, 1994.

[116] J. Ashby and R. W. Tennant, "Chemical structure, Salmonella mutagenicity and extent of carcinogenicity as indicators of genotoxic carcinogenesis among 222 chemicals tested in rodents by the U.S. NCI/NTP," Mutation Research, vol. 204, no. 1, pp. 17-115, 1988.

[117] J. Ashby and R. W. Tennant, "Definitive relationships among chemical structure, carcinogenicity and mutagenicity for 301 chemicals tested by the U.S. NTP," Mutation Research, vol. 257, no. 3, pp. 229-306, 1991, erratum in Mutation Research, vol. 317, p. 175, 1994.

[118] H. S. Rosenkranz Jr., W. T. Speck, and J. E. Stambaugh, "Mutagenicity of metronidazole: structure activity relationships," Mutation Research, vol. 38, no. 3, pp. 203-206, 1976.

[119] F. Van Goethem, D. Lison, and M. Kirsch-Volders, "Comparative evaluation of the in vitro micronucleus test and the alkaline single cell gel electrophoresis assay for the detection of DNA damaging agents: genotoxic effects of cobalt powder, tungsten carbide and cobalt-tungsten carbide," Mutation Research, vol. 392, no. 1-2, pp. 31-43, 1997.

[120] A. Hartmann, H. Fender, and G. Speit, "Comparative biomonitoring study of workers at a waste disposal site using cytogenetic tests and the comet (single-cell gel) assay," Environmental and Molecular Mutagenesis, vol. 32, no. 1, pp. 17-24, 1998. 

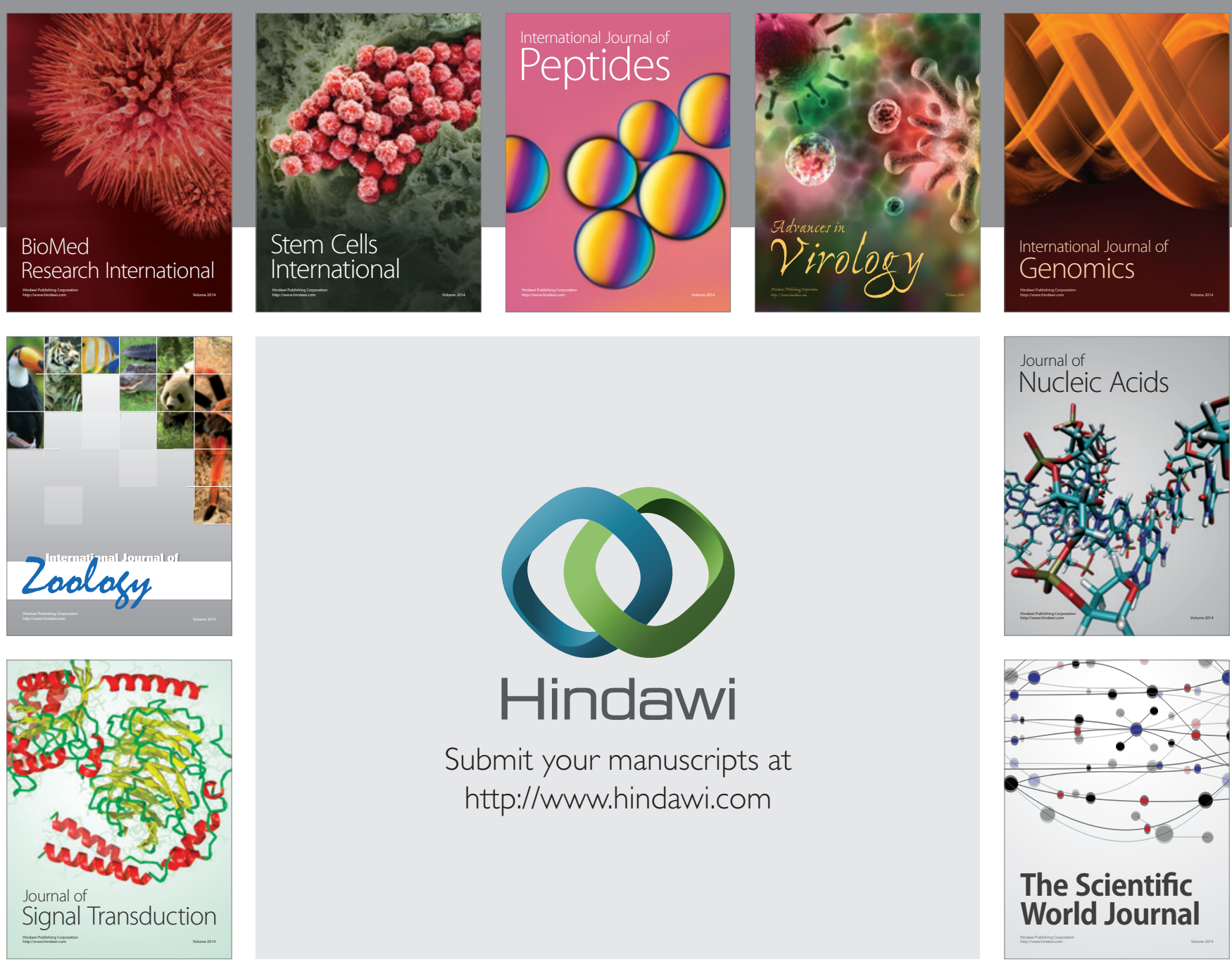

Submit your manuscripts at

http://www.hindawi.com
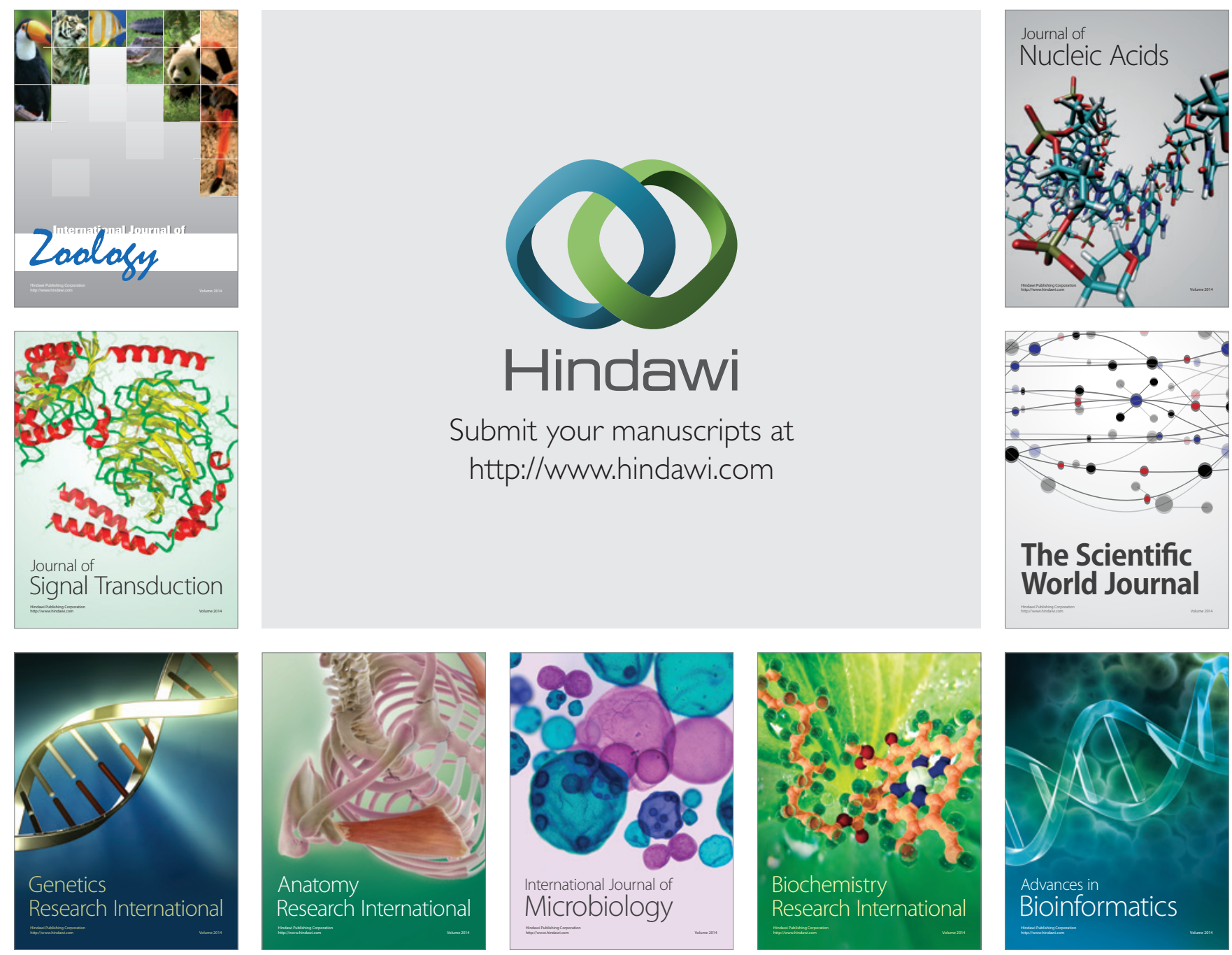

The Scientific World Journal
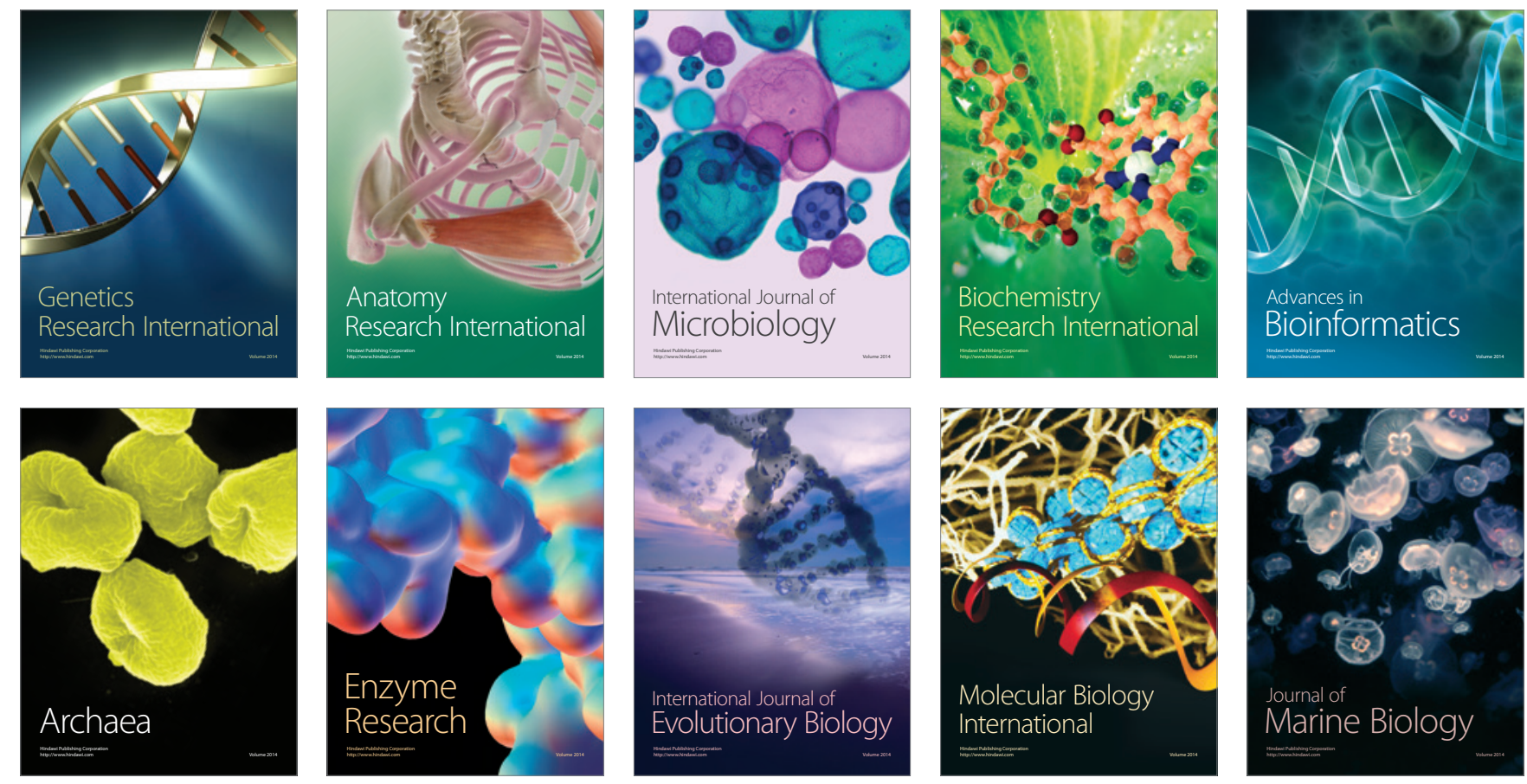